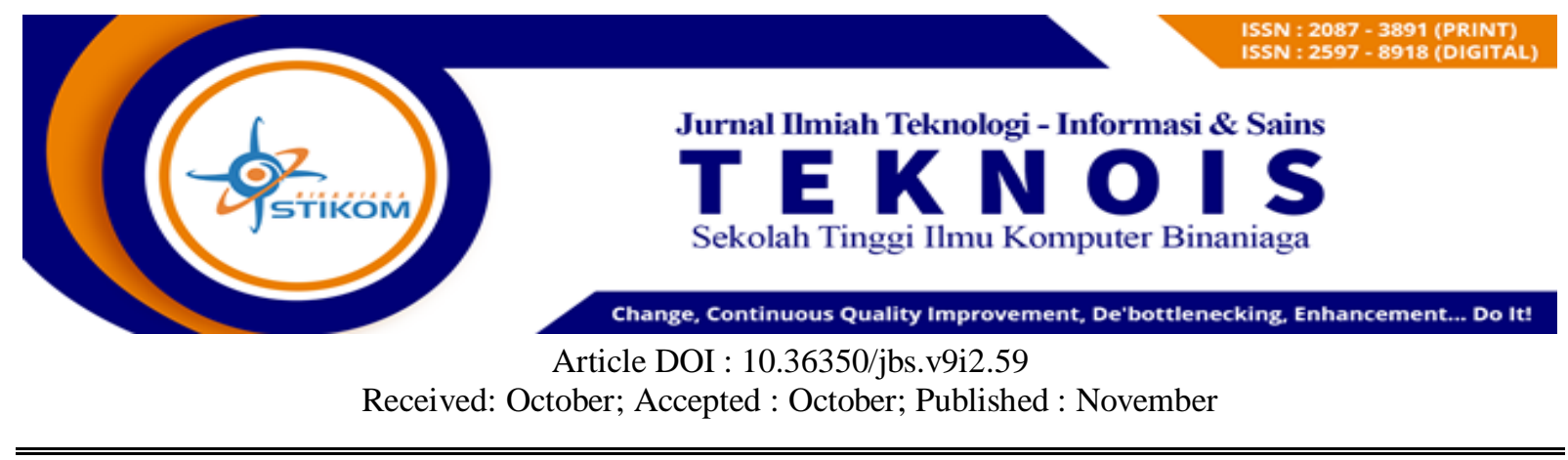

\title{
Mengukur tingkat kebergunaan website dengan menggunakan metode usability
}

\author{
Rajib Ghaniy $^{1^{*}, \text { Millatul Aisyi }^{2}}$ \\ ${ }^{1}$ Sistem Informasi/STIKOM Binaniga \\ Email: rajib@stikombinaniaga.ac.id \\ ${ }^{2}$ Sistem Informasi/STIKOM Binaniga \\ Email: zaman.milla@gmail.com
}

\begin{abstract}
A website can be used as a tool to convey information, therefore the functionality of a website must be measured, the size of a website, good or not, can be measured by the usability method. In a government website in this case is the website of the district government of mamaju, a simple study of the website of the district of mamaju has been carried out, and the results are found that the website users feel the functionality of the website is said to be lacking, to ensure that what is felt by the user is in this case done further research using the usability method to measure the district of mamaju. The mamaju district website can be visited on page www.mamujukab.go.id, the variable usability method used to measure the website is learnability, efficiency, memorability, errors, and satisfaction. Measurements were made to a sample of website users totaling 74 people, the data analysis technique used was the mean method, and questionnaires were distributed using a Likert scale. From the results of this study, it was found that the learnability value was 2.81 , the efficiency value was 2.62, the memorability value was 2.53, the error value was 2.11 , and the satisfaction was 2.50. then the overall value obtained at 2.51 which means that the website mamuju district into the category of not good.
\end{abstract}

Keywords: usabiliti; website; mean; learnability; efficiency; memorability; errors; satisfaction.

\section{ABSTRAK}

Website dapat dijadikan sebuah alat penyampaian informasi, oleh karenanya fungsionlitas sebuah website harus terukur, ukuran sebuah website baik ataupun tidak dapat diukur dengan metode usability. Dalam sebuah website pemerintahan dalam hal ini adalah website pemerintah kabupaten mamaju, telah dilakukan studi sederhana terhadap website kabupaten mamaju, dan didapati hasilnya bahwa pengguna website merasa fungsionalitas dari website tersebut dikatakan kurang, untuk memastikan bahwa apa yang dirasakan oleh pengguna tersebut maka dalam hal ini dilakukan penelitian lanjutan dengan menggunakan metode usability untuk mengukur website kabupaten mamaju. Website kabupaten mamaju dapat dikunjungi di laman www.mamujukab.go.id , variable metode usability yang digunakan untuk mengukur website tersebut adalah learnability, efficiency, memorability, errors, dan satisfaction. Pengukuran dilakukan kepada sampel pengguna website berjumlah 74 orang, teknik analisa data yang digunakan adalah metode mean, dan kuisioner yang disebar menggunakan skala likert. Dari hasil studi ini didapatkan bahwa untuk nilai lernability adalah 2,81, nilai efficiency adalah 2,62, nilai memorability adalah 2,53, nilai error 2,11, dan satisfaction adalah 2,50. maka nilai secara keseluruhan didapat sebesar 2,51 yang mempunyai arti bahwa website kabupaten mamuju masuk kedalam kategori kurang baik.

Keywords: usabiliti; website; mean; learnability; efficiency; memorability; errors; satisfaction. 


\section{A. PENDAHULUAN}

\section{Latar Belakang}

United Nations (UN) meyakini bahwa implementasi teknologi informasi di sektor publik dapat memberikan kesempatan kepada negara kurang berkembang untuk membuat tugastugas yang tidak mungkin menjadi dapat dijangkau dan dicapai (United Nations, 2008). Hampir semua negara berusaha mengadopsi dan menyesuaikan manajemen bisnis dan proses publik mereka dengan kemajuan Teknologi Informasi (TI) dan internet, untuk memigrasikan pemerintah konvensional menjadi layanan e-government. Teknologi informasi sendiri dibuat untuk memudahkan para penggunanya dalam mencatat, mengelola, menyimpan dalam bentuk data, mentransformasikan ke dalam bentuk informasi dan dapat disebarkan untuk para pengguna informasi. Tidak hanya itu, eknologi informasi membantu manusia dalam memecahkan masalah, meningkatkan produktivitas, efektivitas, efisiensi, dan kreativitas.

Salah satu implementasi dari e-government adalah website. Website pemerintah merupakan salah satu media yang sangat bermanfaat bagi warga dan pemerintah (Reddick, 2010). Setiap lembaga pemerintah di Indonesia telah mengembangkan website berdasarkan panduan umum dari Kementerian Informasi dan Teknologi. Demikian juga dengan Pemerintah Kabupaten Mamuju yang telah mengembangkan websitenya pada alamat http://mamujukab.go.id.

Website Pemerintah Kabupaten Mamuju digunakan sebagai sarana pemberi informasi dari pemerintah kabupaten kepada masyarakat. Melihat fungsinya yang sangat penting sudah seharusnya apabila website pemerintah dapat dipahami dengan mudah dan nyaman pada saat digunakan. Berdasarkan peraturan menteri komunikasi dan informatika pada tahun 2017 tentang penyelenggaraan portal dan website pemerintahan, terdapat aturan untuk melakukan pemantauan dan evaluasi yang setidaknya dilaksanakan satu kali dalam satu tahun atau sewaktu-waktu apabila diperlukan.

Untuk pembuktian kualitas website pemerintah Kabupaten Mamuju, penulis telah melakukan uji coba awal dengan penyebaran kuesioner dan responden yang dipilih secara acak. Responden merupakan masyarakat yang tinggal di Kabupaten Mamuju.

Pernyataan 1 - Login

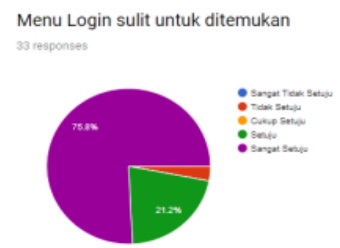

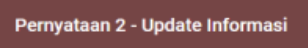
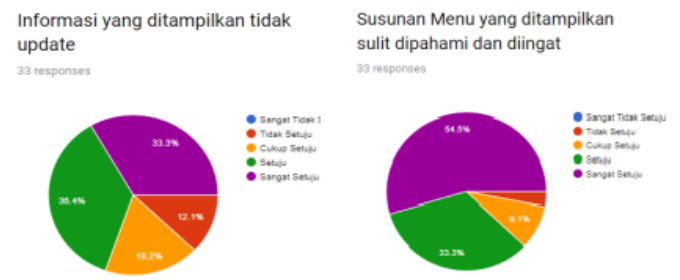

Pernyataan 4 - Menu POTENSI

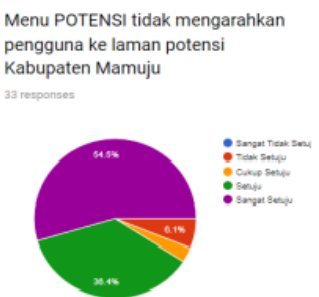

Gambar 1. Hasil Studi Awal Website

\section{Permasalahan}

Dari uraian latar belakang diatas, jika disesuaikan dengan varibel dalam metode usability maka dapat diidentifikasi masalah dalam penelitian ini adalah :

a. Belum diketahui nilai dari learnability pada website pemerintah Kabupaten Mamuju.

b. Belum diketahui nilai dari efficiency pada website pemerintah Kabupaten Mamuju.

c. Belum diketahui nilai dari memorability pada website pemerintah Kabupaten Mamuju.

d. Belum diketahui nilai dari errors pada website pemerintah Kabupaten Mamuju.

e. Belum diketahui nilai dari satisfaction pada website pemerintah Kabupaten Mamuju. 
Volume 9 Number 2 November 2019 Page. 21-31

Journal Homepage : http://teknois.stikombinaniaga.ac.id/index.php/JBS

DOI Link : http://doi.org/10.36350/jbs.v9i2

f. Belum diketahui nilai keseluruhan dari variable usability pada website pemerintah Kabupaten Mamuju.

\section{Tujuan}

Adapun tujuan dari penelitian ini adalah :

a. Untuk mengetahui nilai learnability dari website pemerintah Kabupaten Mamuju

b. Untuk mengetahui nilai efficiency dari website pemerintah Kabupaten Mamuju

c. Untuk mengetahui nilai memorability dari website pemerintah Kabupaten Mamuju

d. Untuk mengetahui nilai errors dari website pemerintah Kabupaten Mamuju

e. Untuk mengetahui nilai satisfaction dari website pemerintah Kabupaten Mamuju

f. Untuk mengetahui nilai keseluruhan dari variable usability pada website pemerintah Kabupaten Mamuju.

\section{Tinjauan Pustaka}

\section{a. Usability}

Kebanyakan orang secara intuitif setuju bahwa kecantikan itu dijual. Sebagai pedoman, website yang indah dan menarik akan lebih banyak menarik pengunjung. Namun, banyak website memberikan terlalu banyak perhatian pada keindahan dan memberikan sedikit perhatian pada kenyamanan para pengunjung. Ketidaknyamanan membuat pengunjung tidak berlama-lama ke website, segera pergi, dan tidak pernah kembali lagi. Untuk membuat pengguna merasa nyaman dan puas, Jakob Nielsen menyatakan bahwa website yang bagus adalah website dengan Learnability (Kemudahan dipelajari), Efficiency (Efisiensi), Memorability (Kemudahan diingat), Errors (Banyaknya kesalahan yang dibuat), dan Satisfaction (Kepuasan pengguna) yang baik bagi semua pengguna website (Nielsen, 2004). Dengan kata lain, website yang bagus adalah website dengan usability yang baik. Lebih lanjut, Shawn Lawton Henry percaya bahwa usability web memengaruhi efektivitas dan efisiensi penggunaan web, meningkatkan kepuasan pengguna, dan usability mewakili peran penting untuk pengembangan website pemerintah (Henry, 2002).

Istilah usability telah dikenal pada awal 1980-an sebagai pengganti istilah "user friendly". Beberapa definisi usability yang disebutkan oleh para ahli sebagai berikut: Usability adalah bagaimana membuat produk yang memenuhi kebutuhan pengguna dan membuatnya lebih mudah digunakan (Nielsen, 2012). Usability didefinisikan oleh komponen-komponen berikut: desain intuitif, kemudahan belajar, efisiensi penggunaan, memori, frekuensi kesalahan, dan kepuasan (Shackel \& Richardson, 1991). Pertama, desain intuitif menggambarkan kenyamanan untuk memahami navigasi dan desain website. Kedua, kemudahan belajar menentukan kemampuan pengguna untuk menggunakan website dan menyelesaikan tugas-tugas dasar untuk pertama kalinya. Ketiga, efisiensi penggunaan menggambarkan kemampuan pengguna yang berpengalaman untuk melakukan tugas. Memorability menjelaskan tingkat kenyamanan pengguna dalam mengunjungi website setelah beberapa waktu tidak mengunjunginya. Keempat, frekuensi dan keparahan kesalahan menentukan tingkat kesalahan pengunjung, seperti: berapa banyak kesalahan yang mereka lakukan, seberapa buruk kesalahannya, dan bagaimana mereka memulihkan kesalahan yang telah mereka lakukan. Dan yang terakhir adalah kepuasan mencerminkan aspek subjektif, apakah pengunjung suka mengunjungi website atau tidak. Jakob Nielsen menyatakan bahwa Usability suatu website adalah kombinasi dari komponen-komponen berikut: Learnability (Kemudahan dipelajari), Efficiency (Efisiensi), Memorability (Kemudahan diingat), Errors (Banyaknya kesalahan yang dibuat), dan Satisfaction (Kepuasan pengguna). Pertama, Kemudahan dipelajari berfokus pada kenyamanan pengguna yang belum pernah melihat website untuk menyelesaikan tugas pada saat pertama kali mereka mengunjungi website. Kedua, efisiensi menangani kecepatan pengguna untuk memenuhi tugas setelah mereka mempelajari website. Ketiga, Kemudahan diingat C2019 Teknois : Jurnal IImiah Teknologi Informasi dan Sains. Copyrights All rights reserved 
menjelaskan betapa mudahnya pengguna mengingat di masa depan setelah terkadang tidak mengunjunginya. Keempat, jumlah kesalahan yang dibuat oleh pengguna, tingkat kejengkelan kesalahan, dan bagaimana memperbaiki kesalahan yang berkontribusi. Dan yang terakhir adalah tingkat Kepuasan mencerminkan seberapa puas pengguna dalam menggunakan website atau aplikasi (Nielsen, 2012). Sehingga bisa disimpulkan bahwa usability sebuah website merupakan suatu istilah yang menunjukkan kemudahan manusia menggunakan suatu alat atau objek buatan manusia lainnya untuk mencapai tujuan tertentu dengan cara memanjakan pengunjung sebuah website dengan lima variabel usability.

\section{b. Website}

Penggunaan internet telah meningkat pesat dan mendorong pertumbuhan potensi pasar. Semua orang menggunakan website hampir disetiap aktivitas, seperti: sekolah, tempat kerja, dan memesan makanan karena prosesnya cepat, murah, mudah, dan menyenangkan. Orang-orang cenderung mencari informasi tentang produk melalui internet sebelum mengunjungi toko. Pengunjung mendapatkan informasi melalui internet melalui website yang terdiri dari teks, gambar, suara, dan animasi (Indayudha, 2008). dengan kumpulan informasi yang disediakan oleh individu, kelompok, atau organisasi, yang di-host pada server dan dapat diakses melalui jaringan (Kurtz \& Boone, 2006). Website adalah salah satu layanan internet yang paling sering digunakan (Raharjo \& Istiyanto, 2003), bagian yang paling terlihat dari internet (Hidayatullah, 2007), tempat dengan nama dan alamat di internet (Talib, 2010), dapat diakses melalui jaringan seperti internet dan Local Area Network (LAN) melalui alamat Internet yang dikenal sebagai Uniform Resource Locator (URL) pada browser (Yuhefizar, et al., 2006). Semua website yang dapat diakses publik secara kolektif disebut sebagai World Wide Web, yang lebih dikenal sebagai WWW.

\section{B. METODE}

Penelitian ini dilaksanakan untuk mengetahui tingkat kebergunaan pada website pemerintah Kabupaten Mamuju berdasarkan lima variabel usability dan menggunakan metode uji yaitu menggunakan kuesioner sebagai teknik untuk mendapatkan tanggapan dari responden. Responden yang digunakan adalah masyarakat Kabupaten Mamuju.

\section{Desain Penelitian}

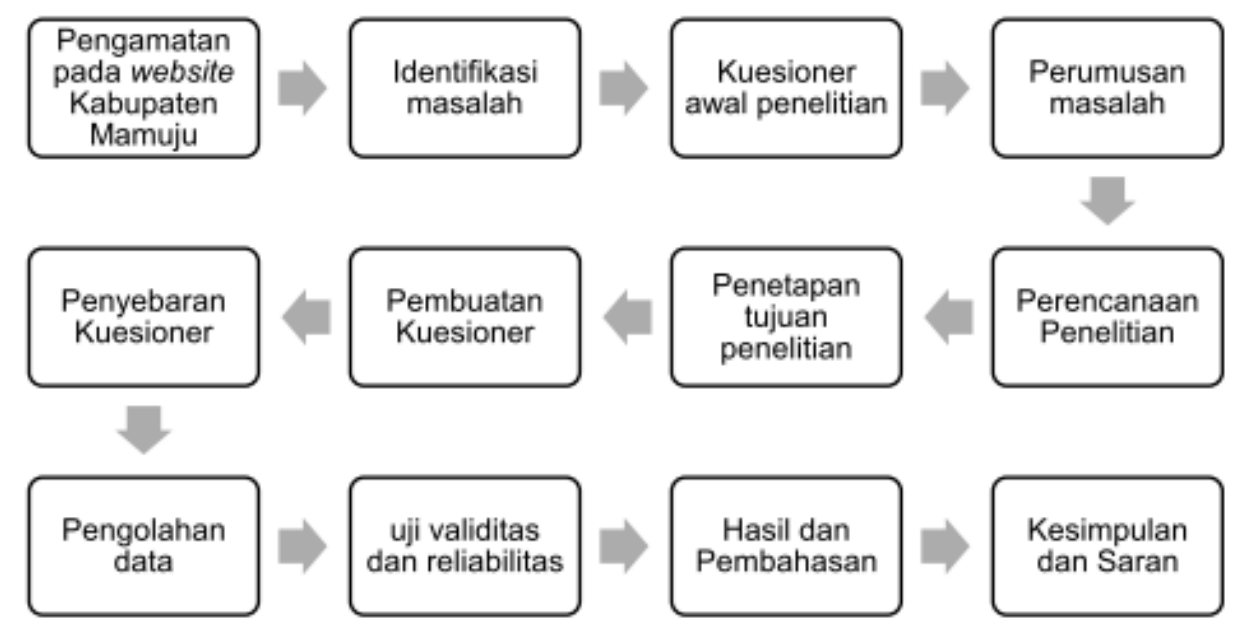

Gambar 2. Prosedur Penelitian

Proses dari prosedur penelitian yang dilakukan dari tahap pertama yaitu observasi atau pengamatan pada website Kabupaten Mamuju sehingga hasil observasi bisa digunakan untuk mengidentifikasi beberapa masalah usability yang ada pada website. Setelah itu penulis 
membuat kuesioner awal untuk pembuktian masalah, karena untuk penelitian tidak boleh hanya dengan menggunakan asumsi saja. Setelah penyebaran kuesioner awal makan didapatkan hasil untuk merumuskan masalah. Selanjutnya penulis merencanakan untuk penelitian dan menetapkan tujuan yang akan dicapai untuk penelitian ini. Untuk tahap kedua kuesioner yaitu pembuatan kuesioner kedua dengan mengacu pada lima variabel usability, yaitu learnability, efficiency, memorability, errors, dan satisfaction. Kuesioner ini berbeda dengan kuesioner awal yang hanya empat pertanyaan untuk mendukung hasil observasi. Responden yang digunakan adalah dengan mendapatkan sampel yang dihitung menggunakan rumus slovin. Kriteria untuk responden yaitu dengan menggunakan data dari BPS yang diantaranya adalah yang tinggal di Kecamatan Mamuju, lulus perguruan tinggi, tinggal di daerah perkotaan, serta mereka yang bekerja. Setelah mendapatkan hasil kuesioner, skor yang didapat dihitung dengan menggunakan skala likert sehingga bisa kita lihat skor berada pada interval baik atau tidak baik. Setelah itu melakukan uji validitas dan reliabilitas sehingga bisa didapatkan hasil yang dapat dianalisis dan bisa ditarik kesimpulan serta saran untuk memperbaiki website pemerintah Kabupaten Mamuju.

\section{Sumber Data}

Sampel diambil berdasarkan data yang didapat dari BPS Kabupaten Mamuju dengan beberapa kriteria. Kriteria pertama yang digunakan adalah responden tinggal di kecamatan Mamuju, yang merupakan pusat perdagangan dan pemerintahan kabupaten Mamuju yang menurut BPS berjumlah 70.309 jiwa pada tahun 2017 (BPS, 2017). Kedua, mereka mengenyam pendidikan perguruan tinggi sebanyak 5.715 jiwa dengan komposisi seperti pada tabel 1 .

Tabel 1. Tingkat Pendidikan

\begin{tabular}{|c|c|}
\hline Pendidikan & Jumlah (orang) \\
\hline Jenjang D I/II & 537 \\
\hline Jenjang D III & 859 \\
\hline Jenjang D IV/S1 & 3902 \\
\hline Jenjang S2/S3 & 417 \\
\hline Total & 5715 \\
\hline
\end{tabular}

Kriteria ketiga, responden merupakan masyarakat perkotaan yang berjumlah sekitar 23,69\%. kriteria keempat adalah mereka yang bekerja sebesar 20,23\% (Sensus Ekonomi, 2016).

$$
\begin{aligned}
\text { Populasi } & =5715 \times 23,69 \% \times 20,23 \% \\
& =5715 \times 0,2369 \times 0,2023 \\
& =273,9 \\
& =274 \text { (dibulatkan) }
\end{aligned}
$$

Setelah dilakukan penghitungan maka di dapat jumlah populasi sebesar 274 orang, sehingga sampel yang digunakan berdasarkan rumus slovin sebesar 10\% dengan rumus sebagai berikut:

$$
\begin{gathered}
n=\frac{N}{1+N e^{2}} \\
n=\frac{274}{1+276 \times 0,1^{2}} \\
n=73,4
\end{gathered}
$$

Maka hasil yang didapatkan untuk sampel minimal dengan rumus diatas sebesar 73,4 dan dibulatkan menjadi 74 orang. 


\section{Instrumen Penelitian}

Pada penelitian ini variabel yang digunakan untuk pertanyaan pada kuesioner adalah berdasarkan lima variabel usability Jacob Nielsen, yaitu:
a. Learnability (mudah dipelajari)
b. Efficiency (Efisien)
c. Memorability (mudah diingat)
d. Errors (banyaknya kesalahan yang terjadi)
e. Satisfaction (kepuasan pengguna)

Berdasarkan variable diatas maka table 2 berikut ini menunjukan indicator untuk kuesioner yang dibuat.

Tabel 2. Indikator Variabel

\begin{tabular}{|c|c|}
\hline Variabel & Indikator \\
\hline \multirow[t]{3}{*}{ Learnability } & Suitability of domain names with website content \\
\hline & $\begin{array}{l}\text { Appropriate appearance with the appearance of the } \\
\text { official website of the government in general }\end{array}$ \\
\hline & $\begin{array}{l}\text { The ease of learning navigation to access each } \\
\text { menu }\end{array}$ \\
\hline \multirow[t]{4}{*}{ Efficiency } & The ease of searching \\
\hline & Ease of $\log$ in \\
\hline & $\begin{array}{l}\text { Ease of accessing one of the menus from the } \\
\text { available menu }\end{array}$ \\
\hline & Information efficiency in headers \\
\hline \multirow[t]{3}{*}{ Memorability } & The ease of remembering the look of the website \\
\hline & Ease of remembering the available menu \\
\hline & $\begin{array}{l}\text { Ease of using the website after leaving and visiting } \\
\text { again in the future }\end{array}$ \\
\hline \multirow[t]{2}{*}{ Errors } & $\begin{array}{l}\text { There are pages that are not available even though } \\
\text { there is a menu }\end{array}$ \\
\hline & Error messages are easy to understand \\
\hline \multirow[t]{4}{*}{ Satisfaction } & $\begin{array}{l}\text { User satisfaction with the completeness of the } \\
\text { information displayed }\end{array}$ \\
\hline & User satisfaction with the information displayed \\
\hline & User satisfaction with the look of the website \\
\hline & $\begin{array}{l}\text { User satisfaction with the time needed to access } \\
\text { website pages (access time) }\end{array}$ \\
\hline
\end{tabular}

\section{Teknik Analisa Data}

Analisis data yang digunakan dalam penelitian ini adalah menggunakan metode statistik Mean (rata-rata), rating scale, serta penghitungan interval. Nilai mean adalah rata-rata yang didapat dari hasil penjumlahan seluruh nilai dari masing-masing data, kemudian dibagi dengan banyaknya data yang ada. Rata- rata disimbolkan dengan $\mathrm{x}$, rumus untuk mean adalah

$$
X=\frac{\sum x i}{n}
$$

\section{HASIL DAN PEMBAHASAN}

\section{Hasil}

\section{a. Responden Kuisioner}

Untuk sumber data yang akan diolah, digunakan kuesioner sebagai alat untuk mengumpulkan data. Kuesioner disebar menggunakan formulir google docs dan responden yang dilibatkan dalam penelitian ini adalah responden yang bertempat tinggal di wilayah Kecamatan Mamuju, lulus perguruan tinggi, tinggal di daerah perkotaan, serta mereka yang bekerja. Berdasarkan penghitungan rumus slovin didapatkan responden berjumlah minimal 74 orang. 
Dari 74 responden yang mengisi kuesioner, responden yang ber jenis kelamin laki-laki berjumlah $41,8 \%$ dan perempuan berjumlah 58,2\%. Usia responden antara 21-30 tahun berjumlah 44,3\% lebih banyak dibanding yang berumur 30-40 tahun yang berjumlah $38 \%$, sedangkan yang berusia di atas 40 tahun hanya sekitar 12,7\%. Untuk Pendidikan tertinggi yang ditamatkan paling banyak adalah lulusan sarjana dengan jumlah 43\%, diikuti oleh magister dan diploma dengan jumlah yang sama yaitu $27,8 \%$.

\section{b. Analisis Statistik}

Hasil rekapitulasi setiap variabel dan perhitungan rata-rata setiap komponen dengan jumlah responden sebanyak 74 orang dan total pertanyaan 17 dijelaskan dalam tabel berikut ini:

1) Learnability

Dengan mengukur kualitas website pemerintah Kabupaten Mamuju berdasarkan variabel Learnability dengan jumlah responden 74 orang, maka didapatkan nilai ratarata yang bisa dilihat pada tabel 3 di bawah ini

Tabel 3. Hasil Rata-rata Variabel Learnability

\begin{tabular}{|c|c|c|c|c|c|c|}
\hline \multirow{2}{*}{ No. } & \multirow{2}{*}{ Responden } & \multicolumn{3}{|c|}{ Learnability } & \multirow{2}{*}{ Total } & \multirow{2}{*}{ Rata-rata } \\
\cline { 2 - 5 } & & $\mathrm{X} 11$ & $\mathrm{X} 12$ & $\mathrm{X} 13$ & & \\
\hline 1. & $\mathrm{R} 1$ & 1 & 1 & 1 & 3 & 1,00 \\
\hline 2. & $\mathrm{R} 2$ & 3 & 4 & 4 & 11 & 3,67 \\
\hline 3. & $\mathrm{R} 3$ & 2 & 1 & 4 & 1,33 \\
\hline 4. & $\mathrm{R} 4$ & 4 & 4 & 4 & 11 & 3,67 \\
\hline 5. & $\mathrm{R} 5$ & $\ldots$ & $\ldots$ & 4 & 11 & 3,67 \\
\hline$\ldots$ & $\ldots$ & 2 & 3 & 2 & $\ldots$ & $\ldots$ \\
\hline 74. & $\mathrm{R} 74$ & 204 & 218 & 202 & 624 & 208.00 \\
\hline \multicolumn{2}{l|}{ Total per indicator } & 2,8 & 2,9 & 2,7 & 8,43 & 2,81 \\
\hline \multicolumn{2}{l}{ Rata-rata per indikator } & & & & & \\
\hline
\end{tabular}

Jadi untuk nilai rata-rata kebergunaan menggunakan variabel Learnability adalah 2.81 .

2) Efficiency

Dengan mengukur kualitas website pemerintah Kabupaten Mamuju berdasarkan variabel Learnability dengan jumlah responden 74 orang, maka didapatkan nilai ratarata yang bisa dilihat pada tabel 4 di bawah ini

Tabel 4. Hasil Rata-rata Variabel Eficiency

\begin{tabular}{|c|c|c|c|c|c|c|c|c|}
\hline \multirow{2}{*}{ No. } & \multirow{2}{*}{ Responden } & \multicolumn{5}{|c|}{ Eficiency } & \multirow{2}{*}{ Total } & \multirow{2}{*}{$\begin{array}{c}\text { Rata- } \\
\text { rata }\end{array}$} \\
\hline & & $\mathrm{X} 21$ & $\mathrm{X} 22$ & $\mathrm{X} 23$ & $\mathrm{X} 24$ & $\mathrm{X} 25$ & & \\
\hline 1 & R1 & 1 & 1 & 1 & 1 & 1 & 5 & 1 \\
\hline 2 & $\mathrm{R} 2$ & 4 & 3 & 4 & 4 & 4 & 19 & 3,8 \\
\hline 3 & R3 & 3 & 1 & 2 & 1 & 2 & 9 & 1,8 \\
\hline 4 & $\mathrm{R} 4$ & 4 & 3 & 3 & 3 & 3 & 16 & 4,0 \\
\hline 5 & $\mathrm{R} 5$ & 4 & 4 & 4 & 4 & 4 & 20 & 5,0 \\
\hline .. & $\ldots$ & $\ldots$ & $\ldots$ & $\ldots$ & $\ldots$ & $\ldots$ & $\ldots$ & $\ldots$ \\
\hline 74 & R74 & 4 & 1 & 1 & 2 & 1 & 9 & 1,8 \\
\hline \multicolumn{2}{|c|}{ Total per indikator } & 236 & 194 & 184 & 189 & 170 & 973 & 194,6 \\
\hline \multicolumn{2}{|c|}{ Rata-rata } & 3,2 & 2,6 & 2,5 & 2,6 & 2,3 & 13,19 & 2,63 \\
\hline
\end{tabular}

Jadi untuk nilai rata-rata kebergunaan menggunakan variabel Efficiency adalah 2.63 . 
Volume 9 Number 2 November 2019 Page. 21-31

Journal Homepage : http://teknois.stikombinaniaga.ac.id/index.php/JBS

DOI Link : http://doi.org/10.36350/jbs.v9i2

3) Memorability

Dengan mengukur kualitas website pemerintah Kabupaten Mamuju berdasarkan variabel Memorability dengan jumlah responden 74 orang, maka didapatkan nilai ratarata yang bisa dilihat pada tabel 5 di bawah ini

Tabel 5. Hasil Rata-rata Variabel Memorability

\begin{tabular}{|c|c|c|c|c|c|c|}
\hline \multirow{2}{*}{ No. } & \multirow{2}{*}{ Responden } & \multicolumn{3}{|c|}{ Learnability } & \multirow{2}{*}{ Total } & \multirow{2}{*}{ Rata-rata } \\
\hline & & $\mathrm{X} 31$ & X32 & X33 & & \\
\hline 1. & R1 & 1 & 1 & 1 & 3 & 1,00 \\
\hline 2. & $\mathrm{R} 2$ & 3 & 4 & 4 & 11 & 3,67 \\
\hline 3. & R3 & 1 & 4 & 1 & 6 & 2,00 \\
\hline 4. & $\mathrm{R} 4$ & 3 & 3 & 3 & 9 & 3,00 \\
\hline 5. & R5 & 4 & 4 & 4 & 12 & 4,00 \\
\hline$\ldots$ & $\ldots$ & $\ldots$ & $\ldots$ & $\ldots$ & $\ldots$ & $\ldots$ \\
\hline 74. & R74 & 2 & 1 & 2 & 5 & 1,67 \\
\hline \multicolumn{2}{|c|}{ Total per indicator } & 187 & 183 & 193 & 563 & 187,67 \\
\hline \multicolumn{2}{|c|}{ Rata-rata per indikator } & 2,52 & 2,47 & 2,6 & 7,6 & 2,53 \\
\hline
\end{tabular}

Jadi untuk nilai rata-rata kebergunaan menggunakan variabel Memorability adalah 2.53 .

4) Errors

Dengan mengukur kualitas website pemerintah Kabupaten Mamuju berdasarkan variabel Errors dengan jumlah responden 74 orang, maka didapatkan nilai rata-rata yang bisa dilihat pada tabel 6 di bawah ini

Tabel 6. Hasil Rata-rata Variabel Errors

\begin{tabular}{|c|c|c|c|c|c|}
\hline \multirow{2}{*}{ No. } & \multirow{2}{*}{ Responden } & \multicolumn{2}{|c|}{ Learnability } & \multirow{2}{*}{ Total } & \multirow{2}{*}{ Rata-rata } \\
\cline { 2 - 4 } & & X41 & X42 & & \\
\hline 1. & R1 & 1 & 1 & 2 & 1,0 \\
\hline 2. & R2 & 3 & 4 & 7 & 3,5 \\
\hline 3. & R3 & 2 & 2 & 4 & 2,0 \\
\hline 4. & R4 & 3 & 3 & 6 & 3,0 \\
\hline 5. & R5 & 4 & 4 & 8 & 4,0 \\
\hline$\ldots$ & $\ldots$ & $\ldots$ & $\ldots$ & $\ldots$ \\
\hline 74. & R74 & 1 & 1 & 2 & 1,0 \\
\hline \multicolumn{2}{|l}{ Total per indicator } & 2,2 & 2,0 & 4,2 & 2,11 \\
\hline \multicolumn{2}{|l}{ Rata-rata per indikator }
\end{tabular}

Jadi untuk nilai rata-rata kebergunaan menggunakan variabel Errors adalah 2.11.

5) Satidfaction

Dengan mengukur kualitas website pemerintah Kabupaten Mamuju berdasarkan variabel Satisfaction dengan jumlah responden 74 orang, maka didapatkan nilai ratarata yang bisa dilihat pada tabel 7 di bawah ini

Tabel 7. Hasil Rata-rata Variabel Satisfaction

\begin{tabular}{|c|c|c|c|c|c|c|c|}
\hline \multirow{2}{*}{ No. } & \multirow{2}{*}{ Responden } & \multicolumn{4}{|c|}{ Eficiency } & \multirow{2}{*}{ Total } & \multirow{2}{*}{$\begin{array}{c}\text { Rata- } \\
\text { rata }\end{array}$} \\
\hline & & X51 & $\mathrm{X52}$ & X53 & X54 & & \\
\hline 1 & $\mathrm{R} 1$ & 1 & 1 & 1 & 1 & 4 & 1,00 \\
\hline 2 & $\mathrm{R} 2$ & 4 & 3 & 3 & 3 & 13 & 3,25 \\
\hline 3 & R3 & 1 & 3 & 1 & 1 & 6 & 1,50 \\
\hline 4 & $\mathrm{R} 4$ & 3 & 3 & 3 & 3 & 12 & 3,00 \\
\hline 5 & R5 & 4 & 4 & 2 & 4 & 11 & 3,50 \\
\hline.. & $\ldots$ & $\ldots$ & $\ldots$ & $\ldots$ & $\ldots$ & $\ldots$ & $\ldots$ \\
\hline
\end{tabular}

(C2019 Teknois : Jurnal Ilmiah Teknologi Informasi dan Sains. Copyrights All rights reserved 
Volume 9 Number 2 November 2019 Page. 21-31

Journal Homepage : http://teknois.stikombinaniaga.ac.id/index.php/JBS

DOI Link : http://doi.org/10.36350/jbs.v9i2

\begin{tabular}{|c|c|c|c|c|c|c|c|}
\hline 74 & R74 & 2 & 3 & 1 & 1 & 7 & 1,75 \\
\hline \multicolumn{2}{|c|}{ Total per indikator } & 215 & 197 & 161 & 168 & 741 & 185,25 \\
\hline \multicolumn{2}{|c|}{ Rata-rata } & 2,9 & 2,7 & 2,2 & 2,3 & 10,0 & 2,5 \\
\hline
\end{tabular}

Jadi untuk nilai rata-rata kebergunaan menggunakan variabel Satisfaction adalah 2.50 .

\section{Pembahasan}

Dalam penelitian ini, hasil pengukuran kebergunaan website pemerintah Kabupaten Mamuju berdasarkan rentang penilaian rata-rata menggunakan skala likert, interpretasi hasil dengan menggunakan rating scale, dan penentuan interval nilai dengan aturan sturgess. Hasil pengukuran kualitas website pemerintah Kabupaten Mamuju untuk semua variabel usability dapat dilihat pada Tabel berikut ini:

Pada tabel 4.23 dapat diketahui bahwa nilai dari kualitas website pemerintah Kabupaten Mamuju untuk tiga parameter adalah kurang baik dan dua parameter lainnya seperti parameter learnability dan efficiency mempunyai nilai cukup, merujuk pada table 3.6. Variabel error mempunyai nilai rata-rata yang paling rendah diantara variabel lainnya. Hal ini dikarenakan responden tidak dapat menemukan halaman potensi di dalam website dan tidak ada notifikasi error ketika halaman tersebut di klik. Jumlah reponden yang sangat setuju dan setuju bahwa menu potensi tidak dapat di buka adalah 48 orang sedangkan jumlah yang sangat setuju dan setuju bahwa tidak ada notifikasi Errors adalah 47 orang.

Untuk hasil pengukuran keseluruhan pada website pemerintah Kabupaten Mamuju nilai ratarata yang didapat adalah 2,51 dan hasil semua analisis di atas website Kabupaten Mamuju memiliki kategori kurang baik untuk hasil pengukuran usability dengan 5 variabel yaitu Learnability, Efficiency, Memorability, Errors, dan Satisfaction. Sehingga ke depan diharapkan pemerintah kabupaten bisa memperbaiki website agar lebih mudah digunakan oleh masyarakat umum.

\section{KESIMPULAN}

Berdasarkan penelitian yang telah dilakukan melalui metode usability dengan lima variabel yaitu learnability, efficiency, memorability, errors, dan satisfaction; dapat diketahui nilai dari masing-masing variabel usability dan nilai total pada website pemerintah Kabupaten Mamuju adalah sebagai berikut:

1. Nilai learnability pada website Pemerintah Kabupaten Mamuju sebesar 2,81 yang menunjukkan bahwa tingkat learnability adalah cukup. Hal ini menjelaskan bahwa website Pemerintah Kabupaten Mamuju sudah cukup mudah dipelajari oleh masyarakat (responden).

2. Nilai efficiency pada website Pemerintah Kabupaten Mamuju sebesar 2,62 dengan kategori cukup. Hai ini menjelaskan bahwa website Pemerintah Kabupaten Mamuju tepat atau sesuai guna.

3. Nilai memorability pada website Pemerintah Kabupaten Mamuju sebesar 2,53 dengan kategori kurang baik. Hal ini menjelaskan bahwa website Pemerintah Kabupaten Mamuju dalam proses penggunaanya kurang mudah untuk diingat.

4. Nilai errors pada website Pemerintah Kabupaten Mamuju sebesar 2,11 dengan kategori kurang baik. Hal ini menunjukkan bahwa website Pemerintah Kabupaten Mamuju kurang baik dalam pencegahan kesalahan.

5. Nilai satisfaction pada website Pemerintah Kabupaten Mamuju sebesar 2,50 dengan kategori kurang baik. Hal ini menunjukkan bahwa pengguna website Pemerintah Kabupaten Mamuju masih kurang puas. 
6. Nilai Usability keseluruhan pada website Pemerintah Kabupaten Mamuju adalah sebesar 2,51 dengan kategori kurang baik, sehingga pengguna menilai bahwa website Pemerintah Kabupaten Mamuju masih kurang berguna.

\section{E. DAFTAR PUSTAKA}

[1] Allen, M., 2013. Michael Allen's Guide to E-learning. Canada: John Wiley \& Sons.

[2] BPS, 2017. Kecamatan Mamuju Dalam Angka. Mamuju: BPS Kabupaten Mamuju.

[3] Dawn Iacobucci, G. A. C., 2010. Marketing Research: Methodological Foundation. Mason, $\mathrm{OH}$ : South-Western Cengage Learning.

[4] DeFranzo, S. E., 2012. Which is More Effective: Paper-Based Surveys or Online Surveys?. [Online] Available at: https://www.snapsurveys.com/blog/which-is-more-effectivepaper-based-surveys-or-online-surveys/ [Diakses 10 Agustus 2018].

[5] Dewanto, I., 2006. Web Desain (Metode Aplikasi dan Implementasi). Yogyakarta: Graha Ilmu.

[6] Edmondson, D. R., 2005. Likert Scales: A History. Charm 2005, Volume 2005, p. 127.

[7] Gant, J. P., 2008. Electronic Government for Developing Countries. Geneva: International Telecommunication Union.

[8] Gillham, B., 2007. Developing a Questionnaire (Real World Research). London: Continuum.

[9] Heeks, R., 2002. Reinventing government in the information age: International practice in IT enabled public sector reform. London: Routledge.

[10] Henry, S. L., 2002. Understanding Web Accessibility. [Online] Available at: https://www.peatworks.org/content/understanding-web-accessibility-standardsconversation-w3cs-shawn-henry [Diakses 10 Agustus 2018].

[11] Malhotra, N., 2006. Questionnaire design and scale development. [Online] Available at: https://www.researchgate.net/publication/266864633_Questionnaire_design_and_scale_ development [Diakses 20 Desember 2018].

[12] Meyers, P., 2009. What Is Usability? [Online] Available at: https://www.slideshare.net/crumplezone/what-is-usability-1289330-1289330-1289330

[Diakses 1008 2018].

[13] Nielsen, J., 2012. Usability 101: Introduction to Usability. [Online] Available at: http://www.nngroup.com/articles/usability-101-introduction-to-usability/

[Diakses 10 agustus 2018].

[14] Pariddudin, Adiat, and Puri Prasastiwi. "Penerapan Metode Webqual 4.0 Untuk Pengukuran Kualitas Website Bprs Al Salaam Amal Salman" Teknois, 2018, doi:10.36350/jbs.v8i2.10.

[15] Supriyatna, Alam, and Rendy Andika. "Mengukur Kualitas Apliaksi Gudang dengan 
Metode USAbility Nielsen" Teknois, 2017, doi:10.36350/jbs.v7i1.29.

[16] Sugiyono, 2018. Metode Penelitian Kuantitatif. Bandung: Alfabeta.

[17] United Nations, 2008. Achieving Sustainable Development and Promoting Development Cooperation. New York: Department of Economic and Social Affairs of United Nations. 